\title{
KEBIRI KIMIA SEBAGAI SANKSI TINDAKAN DALAM DOUBLE TRACK SYSTEM
}

\author{
Ahmad Jamaludin \\ Universitas Islam Nusantara \\ Correspondence: jamaludinumam@gmail.com
}

Received: 27 Maret 2021; Accepted: 24 September 2021; Published: 30 September 2021

\begin{abstract}
The punishment policy in the form of chemical castration for perpetrators of sexual crimes is a confusing policy when viewed from the perspective of a double-track system. The application of castration sanctions is contrary to the purpose of action sanctions in the double-track system because it does not aim to restore the perpetrators, but rather to provide a deterrent effect and retaliation. So that the chemical castration policy is wrong because it is not in accordance with following the principle of action sanctions in the double-track system. The research method used is normative juridical using primary and secondary data and then analyzed qualitatively. This study aims to find out about the double-track system and to determine the action of chemical castration in the perspective of the double-track system. The results of this study show, First in the double-track system, the criminal system is known in two ways, namely, through legal sanctions and witnesses of action, legal sanctions are oriented towards revenge for their behavior while action sanctions are oriented towards improving the perpetrators so that they can be accepted back in the community. The two sanctions for castration are not included as witnesses for acts in the double-track system, because the basic idea is to improve the perpetrators, while chemical castration is more directed at retaliation. This research can be a reference for criminal law policymakers so that the legal policy does not get out of the basic idea of criminal law itself.
\end{abstract}

Keywords: chemical castration action; double track system; punishment.

\begin{abstract}
Abstrak
Kebijakan pemidanaan berupa sanksi tindakan kebiri kimia bagi palaku kejahatan seksual menjadi kebijakan yang membingungkan jika dilihat dalam perpektif double track system. Penerapan sanksi tindakan kebiri kimia bertolak belakang dengan tujuan dari sanksi tindakan dalam sistem double track system dikarenakan tidak bertujuan memulihkan pelaku, namun lebih kepada pemberian efek jera dan pembalasan. Sehingga kebijakan kebiri kimia menjadi kebijakan yang keliru karena tidak sesuai dengan prinsip sanksi tindakan dalam sistem double track system. Penelitian ini menggunakan yuridis normatif dengan menggunakan data primer dan sekunder kemudian dianalisis secara kualitatif. Penelitian ini bertujuan untuk mengetahui tentang double track system dan untuk mengetahui tindakan kebiri kimia dalam perspektif double track system. Hasil penelitian ini menunjukan, Pertama dalam sistem double track system, sistem pemidanaan dikenal dengan dua jalan yakni melalui sanksi
\end{abstract}


hukum dan saksi tindakan, sanksi hukum berorientasi pada upaya balas dendam terhadap prilakunya sedangkan sanksi tindakan berorientasi pada perbaikan pelaku agar bisa diterima kembali di masyarakat. Kedua saknsi tindakan kebiri tidak termasuk saksi tindakan dalam double track system, sebab ide dasarnya perbaikan terhadap pelaku sedangkan kebiri kimia lebih mengarah kepada pembalasan. Penelitian ini dapat menjadi referensi pembuat kebijakan hukum pidana agar kebijakan hukum tersebut tidak keluar dari ide dasarnya hukum pidana itu sendiri.

Kata-kata Kunci: tindakan kebiri kimia; double track system, pemidanaan.

\section{Pendahuluan}

Kekerasan seksual pada anak merupakan kejahatan yang berbahaya dan sangat merugikan kepentingan dan perkembangan anak. Kejahatan ini sudah berjalan lama dan semakin merebak diibaratkan seperti bola salju. Peningkatannya semakin hari semakin banyak dan belum terbendung, ini artinya bahwa jaminan perlindungan anak di Indonesia dari ekspolitasi seksual belum terlaksanakan dengan baik dan belum maksimal. Kasus kekerasan seksual yang semakin banyak menggambarkan bahwa Indonesia belum ramah terhadap anak akibat tingginya kasus kejahatan seksual kepada anak. Peningkatan kejahatan yang terjadi selama tahun 2020 meningkat sekitar 52\% dengan 2700 kasus didominasi kekerasan seksual terhadap anak. ${ }^{1}$

Anak harusnya menjadi garda terdepan untuk dilindungi, sebab anak sebagai generasi penerus yang akan melanjutkan perjuangan bangsa ini, oleh karenanya perlindungan terhadap anak merupakan sebuah kewijiban negara untuk menyelamatkan harkat dan martabatnya demi masa depan anak gemilang dan cerah tanpa kekerasan seksual. Kasus kejahatan sekual pada anak sangatlah berbeda dengan kasus hukum pada umumnya, kasus kekerasan seksual berdamapak serius, karena bisa berefek jangka panjang juga meninggalkan luka mendalam baik secara prikis maupun fisik dan pasti akan berpengaruh terhadap perkembangan emosional anak tersebut yang menjadi korban. ${ }^{2}$

Dewan Perwakilan Rakyat bersama pemerintah telah berupaya untuk menjamin perlindungan bagi anak yang berhadapan dengan hukum dengan melakukan revisi Undang-undang 23 Tahun 2002 menjadi Undang-undang 35 Tahun 2014 Tentang Perubahan Atas Undang-Undang Nomor 23 Tahun 2002 Tentang Perlindungan Anak, yang memperberat hukuman penjara pelaku keja-

1 Vitorio Mantelan, "[Kompas] Komnas PA: Ada 2.700 Kasus Kekerasan Terhadap Anak Selama 2020, Mayoritas Kejahatan Seksual, Diakses Dari,” Kompas, 2020, https://megapolitan.kompas.com/read/2021/01/04/15361151/komnas-pa-ada-2700kasus-kekerasan-terhadap-anak-selama-2020-mayoritas.

2 Nur Hafizal Hasanah and Eko Suponyono, "Kebijakan Hukum Pidana Sanksi Kebiri Kimia Dalam Perspektif HAM Dan Hukum Pidana," Jurnal Megister Hukum Udayana Volume 7, no. 3 (2018): 305-17, DOI: https://doi.org/10.24843/JMHU.2018.v07.i04. p06. 
hatan seksual tersebut, namun revisi Undang-undang Perlindungan Anak tersebut tidak berdampak signifikan terhadap penurunan kasus kejahatan seksual kepada anak serta tidak mampu menjawab keresahan masayarakat terkhusus terhadap kejahatan tersebut. ${ }^{3}$ Puncaknya menurut data KPAI Pada tahun 2014 sampai dengan tahun 2016 angka kejahatan seksual meningkat ${ }^{4}$ dan sangat meresahkan masayarakat. Salah satu kasus menjadi sorotan publik karena dianggap kejam dan membuat masyarakat sangat marah adalah kasus yuyun, siswa SMP yang diperkosa dan dibunuh oleh 14 orang. Akibat dari kasus tersebut masyarakat berbondong-bondong meminta pemerintah untuk mengambil sikap dan memberikan hukuman yang berat kepada palaku kejahatan seksual. ${ }^{5}$

Kondisi inilah yang menjadi pertimbangan Presiden Jokowi sebagai alasan kegentingan yang memaksa untuk mengeluarkan Peraturan Pemerintah Pengganti Undang-undang (Perpu) Nomor 1 Tahun 2016 yang disahkan menjadi Undang-undang Nomor 17 tahun 2016 tentang Perlindungan Anak sebagai perubahan kedua dari Undang-undang Nomor 23 Tahun 2002. Materi muatan Perpu mengatur tindakan kebiri kimia, sanksi tindakan seharusnya mempunyai fungsi terhadap pemulihan dan berefek positif kepada pelaku. ${ }^{6}$ Namun tindakan kebiri dalam Perpu tersebut diyakini akan memberikan efek negative dan memberikan penderitaan kepada yang menerima suntikan kebiri, efek sampingnya adalah dapat mepengaruhi kekuatan tulang sampai mengurangi fungsi otak. ${ }^{7}$

Kebiri kimia akan menekan hasrat dan libido pelaku kejahatan seksual agar hormonnya kehilangan fungsi. Secara teknis kebiri kimia akan bekerja secara efektif ketika senyawa kimia dimasukan kedalam tubuh kemudian bekerja menekan hormon testoteron serta hormon seksual agar tidak bisa berfungsi lagi. Tindakan kebiri kimia diatur dalam pasal 81 ayat 7 dengan syarat-syarat antara lain terdapat trauma kepada korban, korbannya lebih dari satu orang, terdapat luka berat sampai meninggal dunia dan lain sebagainya. Oleh karena itu pemerintah mengaluarkan aturan mengenai mekanisme tindakan kebiri kimia

3 Nuzul Quraini Mardiya, "Penerapan Hukuman Kebiri Kimia Bagi Pelaku Kekerasan Seksual," Jurnal Konstitusi Volume 14, no. 1 (2017): 215-33, DOI: https://doi.org/ 10.31078/jk14110.

4 KPAI, "https://www.kpai.go.id/publikasi/kpai-pelaku-kekerasan-terhadap-anak-tiap-tahunmeningkat, Diakses Pada Tanggal 12 September 2021 Pukul 22.25 WIB," www.kpai.go.id, n.d.

5 Meita Agustin Nurdiana and Ridwan Arifin, "Tindak Pidana Pemerkosaan: Realitas Kasus Dan Penegakan Hukumnya Di Indonesia," Jumal Untidar Volume 3, no. 1 (2019): 52-63, https://doi.org/DOI: http://dx.doi.org/10.31002/lh.v3i1.

6 I Putu Reza Bella Satria Diva and I Gusti Agung Ayu Dike Widhiyaastuti, "Relevansi Pengkualifikasian Sanksi Kebiri Kimiawi Sebagai Sanksi Tindakan Dalam Hukum Pidana," Kertha Wicara: Journal Ilmu Hukum Volume 8, no. 1 (2018): 1-15, https://ojs.unud.ac.id/ index.php/kerthawicara/article/view/49334.

7 Wawancara dengan dokter Dicky Faizal, Spesialis Andrologi, 4 Agustus 2021, Pukul 09.00 WIB 
yang diatur secara rinci dalam Peraturan Pemerintah Nomor 70 tahun 2020 tentang tata cara kebiri kimia. ${ }^{8}$

Faktanya dua narapidana sedang menunggu masa hukuman selesai untuk menghadapi eksekusi tindakan kebiri kimia, mereka adalah Muhammad aris dari Mojokerto dan Rahmat Santoso dari Surabaya. Keduanya telah terbukti bersalah melakukan kejahatan seksual kepada anak dan dijatuhi putusan pengadilan mendapatkan saknsi tindakan kebiri kimia. ${ }^{9}$ Walaupun sampai saat ini dokter menolak menjadi eksekutor kebiri kimia namun putusan pengadilan haruslah dilaksanakan karena sudah berkekuatan hukum tetap. ${ }^{10}$

Memahami tindakan kebiri kimia dalam konsepsinya adalah keliru ketika dikualifikasikan sebagai sanksi tindakan, sebab filosofi ide dasar sanksi tindakan adalah melindungi masyarakat serta perbaikan atau pemulihan kepada pelaku tindak pidana bukan memberikan penderitaan. Berbeda dengan saksi hukuman yang tujuannya adalah melakukan pembalasan, penderitaan kepada pelaku serta mencegah terjadinya kejahatan. ${ }^{11}$ Konsekuensi dari sanksi tindakan kebiri ini kemudian dipertanyakan, apakah kebiri kimia ini tujuannya memberikan pemulihan atau penderitaan, jika kebiri kimia ini memberikan penederitaan pada pelaku kejahatan seksual maka sanksi ini sudah keluar dari tujuan sanksi tindakan itu sendiri.

Beberapa penelitian yang relevan dengan penelitian ini. Pertama, penelitian I Putu Reza Bella Satria Diva dan I Gusti Agung Ayu Dike Widhiyaastuti berjudul Relevansi Pengkualifikasian Sanksi Kebiri Kimiawi sebagai Sanksi Tindakan dalam Hukum. Penelitian tersebut menyatakan bahwa kualifikasi sanksi tindakan kebiri masuk dalam saksi hukuman dalam hukum pidana. ${ }^{12}$ Kedua, penelitian yang dilakukan oleh Dwi Wiharyangti, tentang Implementasi Sanksi Pidana dan Sanksi Tindakan dalam Kebijakan Hukum Pidana di Indonesia, hasil penelitian ini menunjukan bahwa beberapa peraturan perundang-undangan menerapkan sanksi pidana dan sanksi tindakan. ${ }^{13}$ Ketiga, Hyungsoon Park, dengan judul penelitiannya

8 Ahmad Jamaludin and Mohammad Sayid Rifqi Noval, "Pemidanaan Kebiri Terhadap Pelaku Kejahatan Seksual Kepada Anak Perspektif Hak Asasi Manusia Dan Hukum Islam," ADLIYA: Jurnal Hukum Dan Kemanusiaan Volume 14, no. 2 (2020): 191-208, https:/ /doi.org/DOI :10.15575/adliya.v14i2.10135.

9 Andreas Adithya and Maharani Nurdin, "Penerapan Peraturan Kebiri Kimia Bagi Pelaku Kekerasan Seksual Terhadap Anak," Jurnal Kertha Semaya Volume 9, no. 4 (2021): 643-59, https://doi.org/DOI: https://doi.org/10.24843/KS.2021.v09.i04.p08.

10 Kodrat Alam, "Menakar Keterlibatan Dokter Dalam Pelaksanaan Tindakan Kebiri Kimia Bagi Pelaku Kekerasan Seksual Terhadap Anak," Jurnal Hukum Unissula Volume 36, no. 2 (2020): 93-116, https://doi.org/10.26532/jh.v36i2.7561.

11 Barda Nawawi, Kapita Selekta Hukum Pidana (Bandung: Citra Aditya Bahkti, 2003), hlm. 5.

12 Diva and Widhiyaastuti, "Relevansi Pengkualifikasian Sanksi Kebiri Kimiawi Sebagai Sanksi Tindakan Dalam Hukum Pidana."

13 Dwi Wiharyangti, "Implementasi Sanksi Pidana Dan Sanksi Tindakan Dalam Kebijakan Hukum Pidana Di Indonesia," Jurnal Pandecta Volume 6, no. 1 (2011): 80-85, https://doi.org/DOI: https://doi.org/10.15294/pandecta.v6i1.2326. 
Legislative Update: Recent Amendments to South Korean Criminal Law: Confronting Child Sexual Abuse. Hasil penelitian menunjukan bahwa pelaku kekerasan seksual meskipun dihukum berat tidak ada jaminan bahwa mereka tidak akan melakukan kejahatan seskusal lagi. Hukuman berat tidak dapat menjadi solusi mutlak untuk masalah pelecehan seksual anak, selain perlu perawatan yang tepat dan bantuan psikologis perlu dipertimbangkan oleh semua ahli terkait, termasuk pengacara, psikolog, dan profesional lainnya. ${ }^{14}$ Keempat, Melisa Efiyanti dan Gunawan Widjaja, The Implementation of Chemical Castrartion Sanctions Agains Convicts of Child Sexsual Crimes in Indonesia by Doctor, penelitian tersebut menunjukan bahwa pelaksanaan hukuman kebiri kimia sebagai sanksi tambahan harus dilaksanakan dengan memperhatikan ketentuan peraturan perundang-undangan yang memiliki keterkaitan dengan pelaksana tindakan kebiri kimia, sepeti halnya UU Praktik Kedokteran Indonesia dan Kode Etik Kedokteran Indonesia. ${ }^{15}$ Dari beberapa hasil penelitian terdahulu, peneliti mencoba mengkaji, aspek sanksi tindakan terhadap keberlakukuan double track system dalam sistem hukum pidana di Indonesia. dan sanksi tindakan kebiri kimia dalam perspektif double track system.

\section{Metodologi}

Metode penelitian dalam penelitian ini menggunakan metode yuridis normatif, yakni melihat aturan-aturan yang berkaitan dengan tindakan kebiri kimia sebagaimana diatur dalam Undang-undang Nomor 17. Tahun 2016 tentang Perlindungan Anak dan pelaksanaan aturan tersebut dengan menggunakan data primer dan sekunder yakni literatur-literatur yang berupa buku, majalah, jurnal, dan hasil penelitian, yang berkaitan eksekusi tindakan kebiri di Indonesia yang dianalisis secara kualitatif. Untuk melengkapi data penelitian ini, penulis melakukan studi litelatur juga studi lapangan dengan melakukan wawancara dengan pihak yang berkaitan dengan penelitian ini guna mendapatkan jawaban untuk dianalisis dengan teori yang relevan dengan penelitian penulis agar mendapatkan hasil penelitian yang diharapkan. ${ }^{16}$

14 Hyungsoon Park, "Recent Amandements to South Korean Criminal Law: Conforting Child Sexsual Abuse," Australian Journal of Asian Law 14, no. 2 (2013): Article 6: 277-281, https://doi.org/Park, Hyungsoon, Legislative Update: Recent Amendments to South Korean Criminal Law: Confronting Child Sexual Abuse (December 18, 2013). Australian Journal of Asian Law, 2013, Vol 14 No 2, Article 6: 277-281, Available at SSRN: https://ssrn.com/abstract $=2369117$.

15 Mellisa Efiyanti and Gunawan Widjaja, "The Implementation of Chemical Castration Sanctions against Convicts of Child Sexual Crimes in Indonesia by Doctors," Journal of Legal, Ethical and Regulatory Issues Volume 24, no. Special Issue 1 (2021): 1-15, https://www.abacademies.org/abstract/the-implementation-of-chemical-castrationsanctions-against-convicts-of-child-sexual-crimes-in-indonesia-by-doctors-11059.html.

16 Peter Mahmud Marzuki, Penelitian Hukum Edisi Revisi (Jakarta: Kencana Prenada Media Group, 2014), hlm. 133-136. 


\section{Hasil Penelitian dan Pembahasan}

\section{Double Track System dalam Sistem Sanksi Hukum Pidana Indonesia}

Upaya penanggulangan kejahatan, dibutuhkan sebuah kebijakan penetapan sanksi pidana yang sejalan dengan tujuan negara sebagai wujd perlindungan terhadap warganegara sebagaimana UUD 1945. Orientasi kebijakan pidana haruslah selaras dengan prinsip-prinsip yang sudah di atur oleh konstitusi agar tidak melanggar hak-hak warga negara. ${ }^{17}$

Kebijakan pemidanaan sebagaimana teori pemidanaan diklasifikasikan menjadi dua teori yakni teori absolut atau teori pembalasan dan teori reatif atau teori tujuan. ${ }^{18}$ Subtansi teori absolute adalah saksi pidana dijatuhkan karena untuk seseorang telah melakukan kesalahan/kejahatan sebagai upaya pembalasan agar ada efek jera, sedangkan subtansi dari teori relative memandang bahwa saksni pidana yang diberikan pada masayarakat bukah hanya semata-mata memberikan pembalasan atas prilaku seseorang namun juga harus melihat kepentingan pelaku.

Tujuan hukum haruslah memenuhi rasa keadilan masayarakat, ${ }^{19}$ selaras dengan tujuan hukum pidana bukan hanya berorientasi pada pemberian efek jera namun juga berorientasi untuk memperbaiki pelaku kejahatan tersebut. Oleh karenanya dikenalkah konsep double track system. Kebijakan hukum pidana di Indonesia semakin maju, keluar dari tujuan hukum yang bersifat kolonial dan lebih berorientasi pada perbaikan prilaku pelaku kejahatan dalam rangka memanusiakan manusia. Kebijakan hukum pidana kita sudah beralih menuju hukum yang ramah terhadap hak asasi manusia dengan memakai konsep double track system.

Perkembangan hukum pidana dalam menjatuhkan pidana dikenal dengan single track system yaitu sanksi pidana, ${ }^{20}$ namun seiring perkembangan waktu penerapan saksi pidana saja tidak cukup dan efektif dalam mengurangi angka kejahatan maka dikenal dengan double track system yang diyakini akan merubah paradigma pemidanaan di Indonesia yang mengalami kebuntuan dalam menekan kejahatan dan sekaligus membumihanguskan paradigma kolonial bahwa hukum selalu diidentikan dengan memberipembalasan terhadap pelaku kejahatan. Keberanian Indonesia keluar dari hukum kolonial harus dibarengi dengan pembaruan hukum pidana, tanpa pembaruan maka tidak ada artinya hukum Indone-

17 E.Z. Leasa, "Penerapan Sanksi Pidana Dan Sanski Tindakan (Double Track System) Dalam Kebijakan Legislasi," Jurnal Sasi Volume 16, no. Nomor 4 (n.d.): 51-57, https:/ / ejournal.unpatti.ac.id/ppr_paperinfo_lnk.php?id=93.

18 Zainal Abidin Farid, Hukum Pidana 1 (Jakarta: Sinar Grafika, 2007), hlm. 11.

19 Amrunsyah, "Impian Yang Terabaikan : Implementasi Tujuan Hukum Dan Hukum Pidana Di Indonesia," Legalite Jurnal Perundang-Undangan Dan Hukum Pidana Islam Volume 4, no. 2 (2019): 181-204, https://doi.org/https://doi.org/10.32505/legalite.v4iII.1316.

20 Ahmad Rifai Rahawarin, "Tiga Sanksi Hukum Pidana, Ide Pembaharuan Saksi Hukum Pidana Nasional," Jurnal Legal Pluralism Volume 7, no. Nomor 2 (2017): 144-76, http://jurnal.uniyap.ac.id/jurnal/index.php/Hukum/article/view/505: 
sia berubah, justru pembaruan hukum Indonesia itu semangatnya adalah keluar dari jeratan hukum kolonial yang sudah tidak relevan dengan kehidupan bangsa Indonesia.

Pembaruan hukum dimaknai dalam dua arti yakni legal reform dan law reform. Law Reform dimaknai sebagai pembaharuan dalam arti proses sedangkan legal reform dimaknai sebagai pembaharuan hukum dalam arti produk. ${ }^{21}$ Pembaharuan hukum pidana sebagai upaya pembaruan terhadap perbuatan yang dilarang yang dapat dipidana, pelaku dan saksinya. Pembaruan hukum tidak bisa lepas dari politik hukum, keduanya sepeti dua sisi koin yang tidak bisa dipisahkan, pada hakikatnya hukum dibangun atas proses politik dan juga hukum merupakan prodak politik yang berisi norma yang akan diberlakukan dalam masyarakat, politik hukum mencoba melihat arah pembarlakuan norma yang disesuaikan dengan kebutuhan masyarakat, tanpa politik hukum aturan yang dibuat tidak akan mempunyai tujuan dan fungsi sebagai norma, oleh karenanya pembaruan hukum pidana haruslah memperhatikan politik hukum yang ada dalam membuat kebijakan hukum.

Pembahasan mengenai double track system bukanlah sesuatu yang baru dalam ilmu hukum pidana, gagasan double track system muncul sebagai dasar mengeluarkan kebjakan hukum pidana khususnya sanksi pemidanaan. Gagasan double track system juga dikenal dengan nama sistem dua jalur ini berfokus kepada keseimbangan penerapan sanksi pidana terutama sanski pidana dan sanksi tindakan.Ide ini bisa ditelusuri dari aliran klasik menuju aliran modern dan akiran neoklasik. ${ }^{22}$ Walaupun gagasan double track system tidak ditemukan secara eksplisit dalam beberapa litelaur namun gagsan double track system dapat menjadi rujukan pembutan kebijakan hukum pidana terutama di Indonesia, sebab gagasan double track system menginginkan bukan hanya pembalasan terhadap perbuatan namun juga perbaikan terhadap pelaku kejahatan.

Aliran klasik pada prinsipnya hanya menganut single track syistem, yakni sistem sanksi tunggal berupa jenis sanksi pidana. Aliran ini muncul pada abad XVIII yang berpaham indeterminisme mengenai kebebasan kehendak manusia yang menekankan kepada perbuatan pelaku kejahatan sehingga dikehendakilah hukum pidana perbuatan (daad-strafrecht). Karenanya, sistem pidana dan pemidanaan aliran klasik ini sangat menekankan pemidanaan terhadap perbuatan, bukan pada pelakunya. Sistem pemidanaan ditetapkan secara pasti (the definite sentence). Artinya, penetapan sanksi dalam undang-undang tidak dipakai sistem peringanan atau pemberatan yang berhubungan dengan faktor usia, keadaan jiwa pelaku, kejahatan-kejahatan yang dilakukannya terdahulu maupun keadaankeadaan khusus dari perbuatan/kejahatan yang dilakukan.

21 Yesmil Anwar and Adang, Pembaharuan Hukum Pidana (Reformasi Hukum Pidana) (Jakarta: Gramedia, 2008), hlm. 2.

22 M. Sholehudin, Sistem Sanksi Dalam Hukum Pidana-Ide Dasar Double Track System Dan Implementasinya (Jakarta: Raja Grafindo Persada, 2007), hlm. 24. 
Abad XIX lahirlah aliran modern yang mencari sebab kejahatan dengan memakai metode ilmu alam dan bermaksud untuk langsung mendekati atau mempengaruhi penjahat secara positif sejauh dia masih dapat diperbaiki. Bertolak belakang dengan paham aliran klasik, aliran modern memandang kebebasan kehendak manusia banyak dipengaruhi oleh watak dan lingkungannya sehingga tidak dapat dipersalahkan dan dipidana. Andaipun digunakan istilah pidana, menurut aliran modern ini harus tetap diorientasikan pada sifat-sifat pelaku. Karenanya, aliran ini bertitik tolak dari pandangan determinisme dan menghendaki adanya individualis, pidana yang bertujuan mengadakan resosialisasi terhadap pelaku kejahatan.

Aliran Neo-klasik juga menitikberatkan konsepsinya kepada kebebasan kehendak manusia (doconne of free will) telah berkembang selama abad XIX yang mulai mempertimbangkan kebutuhan adanya pembinaan individual terhadap pelaku tindak pidana. ${ }^{23}$ Aliran Neo-klasik menyatakan dengan tegas bahwa konsep keadilan social berdasarkan hukum, tidak realistis dan bahkan tidak adil. Aliran ini berpangkal dari aliran klasik yang dalam perkembangannya kemudian dipengaruhi aliran modern. Ciri dari aliran neo-klasik yang relevan dengan prinsip individualisasi pidana adalah modifikasi dari doktrin kebebasan berkehendak dan doktrin pertanggungjawaban pidana. Modifikasinya antara lain, diterima berlakunya keadaan yang meringankan (mitigating circumstances) baik fiskal lingkungan maupun mental, termasuk keadaan-keadaan lain yang dapat mempengaruhi pengetahuan dan niat seseorang pada waktu terjadinya kejahatan.

Sanksi pidana dan sanksi tindakan mempunyai perbedaan yang mendasar, dan keduanya bersumber dari ide gagasan yang berbeda. Sumber Sanksi pidana merujuk pada Ide dasar "Mengapa diadakan pemidanaan?" sedangkan sanksi tindakan merujuk dari ide dasar "Untuk apa diadakan pemidan itu?". ${ }^{24}$ Bisa kita simpulkan bahwa sanksi pidana bersifat reaktif terhadap suatu perbuatan kejahatan sedangkan sanksi tindakan lebih antisipatif terhadap pelaku kejahatan. Jika fokus sanksi pidana bertumpu pada perbuatan seorang melalui pemberian penderitaan sebagai upaya untuk memberikan efek jera, sedangkan sanksi tindakan adalah pada upaya memberi jalan agar seseorang tersebut bisa berubah dan kembali kepada masyarakat tanpa ada sterotip.

Sanksi pidana bertujuan untuk melakukan balasan atas perbuatan seseorang yang melakukan kejahatan dengan diberikan penderitaan yang sengaja dibebankan kepada seorang yang melanggar hukum. Sedangkan sanksi tindakan muncul karena untuk melakukan perlindungan terhadap masyarakat dan pembinaan atau perawatan bagi orang yang melanggar hukum tersebut.

23 Syaiful Bakhri, "Pengaruh Aliran-Aliran Falsafat Pemidanaan Dalam Pembentukan Hukum Pidana Nasional," Jurnal Hukum Ius Quia Iustum Volume 18, no. 1 (2011): 136-57, https://doi.org/10.20885/iustum.vol18.iss1.art8.

24 Sholehudin, Sistem Sanksi Dalam Hukum Pidana-Ide Dasar Double Track System Dan Implementasinya, hlm. 32 . 
Sejalan dengan pemidanaan di Indonesia, sistem double track system di praktikan oleh Indonesia dalam sistem pemidanaannya yakni penerapan dikenal dengan sistem dua jalur. Termasuk Indonesia dalam sistem pemidanaan menerapkan sistem dua jalur, yaitu memberikan saksni pidana bagi siapa saja yang melakukan perbuatan jahat/pelanggaran dan juga dapat dikenakan sanksi tindakan. Dalam KUHP saksni tindakan diberlakukan bagi orang yang tidak mampu bertanggung jawab dan juga bagi orang yang mampu bertanggung jawab, penerapan kebijakan sanksi tindakan di Indoensia dikarenakan belum efektifnya sanksi pidana dalam menekan angka kejahatan. ${ }^{25}$

Pemberlakuan sanksi pidana dan sanksi tindakan di Indonesia dalam dua bentuk, yakni diatur dalam KUHP dan diatur diluar KUHP. Aturan sanksi pidana dan tindakan diatur dalam pasal 10 KUHP yakni pidana pokok antara lain pidana mati, penjara, kurungan, denda dan kurungan, serta pidana tambahan antara lain pencabutan hak-hak tertentu, perampasan barang tertentu serta pengumuman putusan hakim. Sedangkan sanksi tindakan dalam KUHP diatur dalam pasal 44 KUHP hanya dapat dikenakan bagi orang yang tidak mampu bertanggung jawab karena cacat jiwanya atau terganggu akibat penyakit. ${ }^{26}$

Aturan diluar KUHP, sanki tindakan dan pidana diatur dalam beberapa peraturan perundang-undangan antara lain, Pertama, Undang-undang Nomor. 32 Tahun 2009 Tentang Narkotika yakni selain sanki pidana berupa penjara, pidana mati, kurungan dan denda juga terdapat sanksi tindakan berupa rehabilitasi bagi pelaku kejahatan narkotika. Kedua, diatur dalam Undang-undang Nomor 3 Tahun 1997 jo Undang-undang Nomor 23 Tahun 2002 tentang Perlindungan Anak mengatur sanki pidana berupa penjara, kurungan dan denda juga terdapat sanksi tindakan berupa dikembalikan kepada orang tua bahkan dalam Undang-undang Nomor. 17 Tahun 2016 tentang Perlindungan Anak mengatur dan menerapkan sanksi tindakan kebiri bagi pelaku kejahatan seksual. Ketiga, dalam Undang-undang Nomor. 32 Tahun 2009 Tentang Perlindungan dan Pengelolaan Lingkungan Hidup mengatur sanksi pidana berupa penjara, kurungan dan denda juga terdapat sanksi tindakan berupa perampasan keuntungan, penutupan ijin dan perbaikan lingkungan.

\section{Sanksi Tindakan Kebiri dalam Perspektif Double Track System.}

Kebijakan tindakan kebiri bermula dari banyaknya kasus-kasus kejahatan seksual pasca perubahan Undang-undang Nomor. 23 Tahun 2002 kemudian diubah menjadi Undang-undang Nomor. 35 Tahun 2014 Tentang Perlindungan Anak. Revisi undang-undang tersebut memperlihatkan keseriusan negara untuk

25 Wiharyangti, "Implementasi Sanksi Pidana Dan Sanksi Tindakan Dalam Kebijakan Hukum Pidana Di Indonesia."

26 Gita Santika Ramadhani, Barda Nawawi Arief, and Purwoto, "Sistem Pidana Dan Tindakan 'Double Track System' Dalam Hukum Pidana Di Indonesia," Jurnal Diponegoro Law Review 1, no. 4 (2012): 1-9, http://ejournal-s1.undip.ac.id/index.php/dlr. 
mencegah dan menanggulangi kejahatan seksual kepada anak dengan memperberat hukuman pokok dan denda, setelah belakunya revisi undang-undang Perlindungan Anak tersebut selama 2 tahun sampai tahun 2016, revisi undang-undang tersebut dianggap tidak efektif dan tidak memberikan efek jera kepada pelaku kejahatan seksual, bahkan kasus tindakan kekerasan kesusal cenderung sadis dan menjadi perhatian publik. Beberapa kasus kejahatasn seksual tidak dilakukan sendri namun secara bersama-sama, bahkan yang menjadi pelakunya adalah orang terdekat dari korban itu sendiri. Muncullah inisisasi dari beberapa lembaga untuk memperberat hukuman penjahat paedofilia bukan hanya diberikan hukuman penjara dan denda namun juga perlu ada pidana tambahan lagi antara lain pengumuman identitas paedofilia, pemasangan alat deteksi eletronik untuk mengetahui keberadaan palaku kejahatan seksual serta kebiri kimia.

Disisi yang lain ketika isu pemberatan hukuman bagi palaku kejahatan seksual muncul ke publik terutama mengenai kebiri kimia, beberapa oraganisasi kemasyarakatan dan beberapa lembaga negara termasuk organisasi profesi menolak inisisasi hukuman kebiri tersebut, diantaranya Komnas HAM, Ikatan Dokter Indonesia, Komnas Perempuan dan beberapa organisasi kemasyarakatan lainnya. Alasannya beragam, diantaranya ada yang berpendapat bahwakebiri kimia melanggar hak asasi manusia dan juga belum terujinya kebiri kimia menjadi hukuman yang dapat menekan angka kejahatan seksual, termasuk organisasi profesi dokter Ikatan Dokter Indonesia (IDI) yang menolak menjadi eksekutor tindakan kebiri karena bertentangan dengan kode etik kedokteran.

Pemberlakukan kebijakan tindakan kebiri kimia yang diatur dalam pasal 81 ayat 7 UU Perlindungan anak yang dikualifikasikan sebagai tindakan medis yang terkualifikasi sebagai hukuman badan, sebab tindakan kebiri merupakan tindakan untuk menekan keinginan dan libido seksual seseorang yang dapat menyiksa pelaku tidak berorientasi pada penyembuhan atau rehabilitasi terhadap pelaku kejahatan seksual dan lebih menitikberatkan pada pembalasan terhadap perbuatanya tersebut.

Perumusan sanksi tindakan kebiri di Asia pertama kali diterapkan adalah di Korea Selatan. ${ }^{27}$ Tahun 2011 Korea Selatan memperkenalkan penggunakan tindakan kebiri kimia pada pelaku kejahatan seksual. Pelaku kejahatan seksual terhadap anak di bawah umur (kurang dari 16 tahun tahun) dikenakan tindakan kebiri kimia. Beberapa padangan saat itu menyerukan agar diterapkan hukuman yang lebih keras terhadap pelanggar seksual.

Di Indonesia proses penyusunan kebijakan hukum pidana seharusnya terencana dan tersusun secara baik dan dapat diterma oleh masayarakat, sebab pada hakikatnya hukum pidana haruslah melindungi bukan hanya kepentingan individu namun juga masyarakat secara umum, selain itu juga dalam menyusun

27 Joo Young Lee and Kang Su Cho, "Chemical Castration Fo Sexsual Offenders: Physician' View," JKMS Journak Korean Medical Science) Volume 28, no. 2 (2013): 171-72, https://doi.org/http://dx.doi.org/10.3346/jkms.2013.28.2.171. 
kebijakan hukum pidana harusnya sesuai dengan yang digariskan oleh ilmu pengetahuan dalam hal ini adalah ilmu hukum pidana dan pemidanaan. ${ }^{28}$ Sehingga kebijakan hukum yang dihasilkan setidaknya tidak menimbulkan polemik yang berkepanjangan, kebijakan hukum tersebut harus bisa diterima dan ditegakan oleh seluruh masyarakat.

Menurut dr. Dicky Faizal ${ }^{29}$ dokter sepesialis andrologi mengatakan bahwa tindakan kebiri kimia merupakan tindakan penekanan hasrat dengan memberikan sesuatu senyawa yang tujuan akhirnya adalah menekan hormon supaya turun Dengan penurunan libido yang terjadi akan membuat orang tersebut tidak mempunyai ketertarikan lagi terhadap lawan jenisnya. Disisi lain dampak yang ditimbulkan dari kebiri kimia akan sangat berbahaya, seperti menimbulkan esteoporosis dan juga ada dampak psikologis kepada orang tersebut, bahkan bisa menjadikan depresi. Melihat proses dan dampak dari tindakan kebiri ini tentu tindakan kebiri ini lebih berfokus kepada upaya balas dendam atas nama korban serta upaya menekan kejahatan seksual terhadap anak tanpa mempertimbangkan efek samping dalam jangka waktu yang panjang terhadap pelaku kejahatan seksual tersebut.

Sanksi tindakan dalam double crack system mempunyai konsekunsi hukum yang berbeda dengan sanksi hukuman. ${ }^{30}$ Kebijakan hukum pidana dalam menentukan sanksi tindakan harus sesusai ide dasar/gagasan dari sanksi tindakan itu sendiri juga diperlukan kehati-hatian dalam merumuskan sanksi tersebut agar bisa diterima dan dilaksanakan oleh masyarakat termasuk aparat penegak hukum.

Sanksi tindakan kebiri kimia dalam aspek teori pemidanaan memiliki tujuan untuk melumpuhkan atau membuat seorang pelaku kejahatan kekerasan seksual tidak lagi mampu untuk melakukan perbuatannya. Sanksi ini bertujuan untuk melumpuhkan pelaku tidan pidana kejahatan kekerasan seksual, hal ini bersumber dari teori yang berasal dari teori pelumpuhan atau inkapasitasi. Teori inkapasitasi yaitu sebagai suatu tindakan yang mengakibatkan seseorang tidak mampu untuk melakukan tindak pidana. Peter W. Low berpandangan bahwa tujuan pemidanaan berdasarkan teori pelumpuhan ini adalah untuk mencegah, atau mengurangi peluang seseorang untuk melakukan tidakan kejahatan yang sama. Tindakan kebiri kimia ini pada dasarnya sejalan dengan tujuan dari teori pelumpuhan tersebut, dengan tujuan agar pelaku kejahatan kekerasan seksual tidak melakukan kejahatan tersedbut dikemudian hari. ${ }^{31}$

28 Supiyati, "Kebijakan Hukum Kebiri Kimia Terhadap Pelaku Kejahatan Seksual Dalam Perspektif Pemidanaan,” Rechtsregel Jurnal Ilmu Hukum Volume 3, no. 2 (2020): 247-58, https://doi.org/DOI: http://dx.doi.org/10.32493/rjih.v3i2.8093.

29 Wawancara dilakukan pada tanggal 4 Agustus 2021 melalui Aplikasi Zoom Meeting pukul $09.00 \mathrm{WIB}$

30 Ramadhani, Arief, and Purwoto, "Sistem Pidana Dan Tindakan 'Double Track System' Dalam Hukum Pidana Di Indonesia."

31 I Nyoman Ngurah Suwarnatha, "Tujuan Pemidanaan Sanksi Tindakan Kebiri Kimia Bagi Pelaku Kekerasan Seksual Terhadap Anak Prosiding, "Merekontruksi Ilmu Hukum Dan 
Pemberlakukan hukuman kebiri kimia tidak menjamin dapat menekan, mengurangi atau bahkan menghilangkan agresifitas pelaku kejahatan seksual, selama mental pelaku/penjahat seksual tersebut tidak diobati. Sebagaimana penelitian yang dilakukan oleh Hyungsoon Park bahwa pelaku kekerasan seksual meskipun dihukum berat, tidak ada jaminan bahwa mereka tidak akan melakukan kejahatan seskusal lagi. ${ }^{32}$ Sanksi tindakan kebiri kimia ini berkemungkinan akan menimbulkan rasa dendam dan bisa jadi lebih nekat karena perlakuan yang dia terima selama mendapatkan tindakan kebiri kimia. ${ }^{33}$ Menurut Siti Aminah ${ }^{34}$ kejahatan seksual tidak hanya bicara soal penetrasi dari alat kelamin laki-laki. Namun pelaku dapat menggunakan alat lain untuk agar memenuhi hastrat seksual dan dendamnya, diantaranya bisa dengan menggunakan benda atau alat bantu sekual lainnya.

Tindakan kebiri kepada pelaku kajahatan seksual akhirnya hanya menambah beban negara, selain mekanismenya masih ditolak oleh dokter yang ditunjuk sebagai eksekutor tindakan kebiri, juga tindakan kebiri ini dianggap akan menyerap biaya yang mahal dan yang terpenting adalah tindakan kebiri ini tidak secara langsung tidak berdampak terhadap korban kejahatan seksual, artinya tindakan kebiri tidak serta merta dapat mengobati rasa sakit terhadap korban, dan seolah tindakan kebiri ini mengabaikan upaya pemulihan korban akibat kejahatan seksual yang dialaminya.

Tindakan kebiri sama sekali tidak mencerminkan upaya untuk melakukan perbaikan serta rehabilitasi terhadap korban namun lebih kepada pembalasan atas nama korban yang efektiffitasnya juga dipertanyakan. jika kita melihat ketentuan Pasal 81 ayat 8 Undangundang Perlindungan Anak sangatlah jelas bahwa dalam aturan tersebut saknsi bagi pelaku kejahatan seksual terjadi double punishment, saksi pidana dan tindakan namun secara esensial sama, keduanya mengarah kepada pembalasan terhdap pelaku, hal tersebut bertentangan dengan ide dasar sanksi tindakan itu sendiri yang harusnyan berorientasi pada memperbaiki pelaku, bukan memberikan penderitaan sedangkan sanksi kebiri kimiawi bukanlah merupakan suatu bentuk sarana rehabilitasi yang bisa memperbaiki atau merehabilitasi pelaku kejahatan seksual..$^{35}$

Ilmu Sosial Dalam Membangun Karakter Bangsa," Seminar Nasional Hukum Dan Ilmu Sosial Ke 2 Volume 2, no. 2 (2018), http://eproceeding.undiksha.ac.id/index.php/ SENAHIS/index.

32 Park, "Recent Amandements to South Korean Criminal Law: Conforting Child Sexsual Abuse."

33 Supriyadi Widodo and et. al., Menguji Euforia Kebiri: Catatan Kritis Atas Rencana Kebijakan Kebiri (Chemical Costration) Bagi Pelaku Kejahatan Seksual Anak Di Indonesia (Jakarta Selatan: Aliansi 99 Tolak Perppu Kebiri, 2016), hlm. 22.

34 Wawancara dengan Komisioner Komnas Perempuan tanggal 15 Agustus 2021 pukul 16.00 WIB

35 Gusti Ngurah Yulio, "Tinjauan Yuridis Terhadap Hukuman Kebiri Terhadap Pelaku Kekerasan Seksual Kepada Anak," Jurnal Kertha Wicara FH Universitas Udayana Volume 7, no. 2 (2018): 1-9, https://ojs.unud.ac.id/index.php/kerthawicara/article/view/39473. 
Sanksi tindakan haruslah dimaknai sebagai pembaruan hukum pidana, sebab orientasinya pemidanaan sudah berubah dan bergerak lebih maju demi perbaikan masadepan manusia. Pembaharuan hukum pidana haruslah berbentuk kebijakan hukum pidana yang berbeda dari sebelumnya, namun tidak dengan tindakan kebiri yang merupakan tindakan yang berorientasi pada penghukuman keluar dari paradigma sanksi tindakan yang sebenarnya. Saksi tindakan adalah pembeda atas hukum yang dibuat kolonial yang sudah kita pakai lebih dari seratus tahun. Namun nyatanya saksi tindakan kebiri adalah kebijakan reaktif dan latah, tanpa berfikir jangka panjang dan terjebak pada opini publik yang merusak sistem pemidanaan terutama sistem saksi tindakan.

Kesimpulan dari aturan tersebut, tindakan kebiri diputuskan bersamaan dengan hukuman pokok, hal ini menimbulkan kehawatiran terjadi dua hukuman yang sama, baik hukuman pokok maupun tindakan kebiri sama mempunyai sifat balas dendam terhadap pelaku paedofilia, jika demikian maka konsep pemidanaan tersebut keluar dari sistem double track system. ${ }^{36}$

Kebijakan ini akan mengalami hambatan terutama dalam pelaksanaan eksekusi tindakan kebiri kimia oleh dokter, walaupun sudah secara tegas diatur bahwa dokter merupakan orang yang berwenang melakukan eksekusi tindakan kebiri, namun sampai saat ini dokter menolak dengan alasan bertentangan dengan kode etik profesi kedokteran, serta belum terbukti secara ilmiah menekan angka kejahatan seksual. Hal ini menandakan bahwa kebijakan hukum pidana berkaitan tindakan kebiri adalah aturan yang tidak mempunyai ruh dan semangat yang sama untuk menanggulangi bahaya predator anak. Alhasil, kebijakan kebiri kimia ini menimbulkan kebingungan bagi para penegak hukum, terutama bagi jaksa sebagai orang yang memiliki kewenangan melaksanakan putusan pengadilan. Walaupun pelaksanaan putusan tentang kebiri kimia ini masih menunggu selesainya hukuman pokok, namun dari infrastruktur penegakan hukumnya sama sekali tidak terlihat siap bahkan cenderung gagap.

Dokter pada saat menjalankan profesinya, terikat oleh aturan baik aturan perundang-undangan maupun norma etik yang sudah disepakati para dokter. Apa yang dilakukan dokter terhadap pasiennya semata-mata untuk mengobati, bukan menyakiti pasien itu sendiri. Dokter sebagaimana amanat Undang-undang Praktik Kedokteran merupakan orang yang berhak melakukan tindakan medis dengan persetujuan pasien dan demi kepentingan pasien. ${ }^{37}$ Berbeda dengan tugas melakukan eksekusi tindakan kebiri kimia, seolah-olah dokter jadi tameng dan tidak jelas perlindungan kepada dokternya terutama mengenai

36 Luh Nia Sasmita and Gde Made Swardhana, "Sanksi Kebiri Kimia Dalam Konteks Pembaharuan Hukum Pidana Di Indonesia," Jumal Kertha Semaya 9, no. No. 7 (2021): 1121 1130, https://doi.org/DOI: https://doi.org/10.24843/KS.2021.v09.i07.p04.

37 Wiwik Afifah, "Kewenangan Dokter Dalam Melakukan Eksekusi Hukuman Kebiri," AlDaulah Jurnal Hukum Dan Perundangan Islam Volume 10, no. 2 (2020): 304-35, https://doi.org/DOI: https://doi.org/10.15642/ad.2020.10.2.303-335. 
pertentangan dengan etik. Pemerintah seolah-olah tutup mata mengenai benturan etik yang dialami dokter. Hal ini lah yang membuat dokter malalui Ikatan Dokter Indonesia (IDI) menolak sebagai eksekutor, walaupun sudah diatur dalam PP Nomor 70 Tahun 2020 tentang Tata Cara Kebiri Kimia.

Definisi mengenai sanksi tindakan dalam tindakan kebiri kimia harus diperbaiki agar tindakan kebiri kimia secara subtansi bisa laksanakan oleh aparat penegak hukum termasuk dokter. Jika tindakan kebiri kimia ide dasarnya memperbaiki paedofil, sebagaimana ide dasar double crack system maka kemungkinan konsepnya bukan lagi berorientasi pada upaya balas dendam, tapi mengobati prilaku seksual yang berlebihan dan menyimpang serta diangap penyakit. Dengan begitu, dokter dapat menangani kasus tersebut dengan prosedur yang sudah diatur melalui aturan praktik kedokteran tanpa harus melanggar etika profesi, sebab konsepnya adalah tindakan medis untuk menyembuhkan penyakit yang ada dalam tubuh paedofilia.

Pemidanaan harusnya bukan hanya memberikan efek jera terhadap pelaku tindak pidana kekerasan seksual, namun juga harus berorientasi terhadap perbaikan pelaku kejahatan agar bisa diterma kembali di masyarakat, hal ini selaras dengan paradigma baru pemidanaan di Indonesia dari retributive menjadi restoratif. ${ }^{38}$ Pada hakikatnya tujuan pemidanaan di Indonesia berlandaskan nilai Pancasila yang harus menjadi perhatian adalah dengan pendekatan multidimensi terhadap dampak sebuah kejahatan. Sehingga tujuan pemidanaan harus memperbaiki kerusakan baik bersifat individu maupun sosial akibat dari tindak pidana. Oleh karenanya tujuan pemidanaan haruslah berorientasi pada pandangan yang lebih komprehensif dan menyeluruh serta saling terintegrasi yang terdiri dari seperangkat tujuan pemidanaan yang harus di penuhi. Hukum pidana tidak boleh beroreintasi pada aspek perbuatan manusia, yang akhirnya hukum pidana menjadi tidak manusiawi karena mengutamakan pembalasan dinbandingkan perbaikan. Sama halnya hukum pidana tidak memperhatikan pelaku, karena akan memiliki kesan memberikan karpet merah kepada penjahat dan tidak melihat kepentingan masyarakat luas terutama kepentingan korban. ${ }^{39}$

Berkaitan dengan tujuan pemidanaan, maka pemerintah beserta Dewan Perwakilan Rakyat perlu untuk melakukan evaluasi terhadap kebijakan tindakan kebiri kimia yang tidak sesuai dengan prinsip dan ide dasar double crack system. Sejatinya saksi tindakan harus memberikan pembaruan dalam hukum pidana sebab orientasinya adalah untuk memperbaiki pelaku agar kelah dia bisa hidup kembali dalam masyarakat dan diharapkan tidak mengulangi tindak pidana dikemudian hari.

38 Eva Achjani Zulfa, "Pergeseran Paradigma Pemidanaan Di Indonesia," Jurnal Hukum Dan Pembangunan Fakultas Hukum Universitas Indonesia Volume 36, no. 3 (2006): 399, https://doi.org/DOI: http://dx.doi.org/10.21143/jhp.vol36.no3.1256.

39 Eko Suponyono, "Kebijakan Perumusan Sistem Pemidanaan Yang Berorientasi Pada Korban,” Jurnal MMH Volume 41, no. Nomor 1 (2012): 29-40, https://doi.org/DOI: 10.14710/mmh.41.1.2012.29-41. 
Saran penulis dari hasil penelitian ini adalah pemerintah segera mengkaji ulang serta menghapus kebijakan sanksi tindakan kebiri sebagai sanksi tindakan karena tidak sesuai dengan konsep dan prinsip double crack system. Kedua, Pemerintah seharunya mampu untuk mengkategorikan sanksi pidana terhadap pelaku kejahatan seksual dengan bentuk tindakan rehabilitasi dengan tujuan untuk memperbaiki pelaku kejahatan seksual menjadi lebih baik, dikarenakan dalam pelaksanaanya dibeberapa negara di dunia yang menerepakan kebiri kimia, juga tidak berjalan secara efektif, hal ini didasarkan atas panjangnya proses pelaksanaan tindakan kebiri kimia terhadap pelaku kejahatan seksual.

\section{Kesimpulan}

Berdasarkan hasil pembahasan permasalahan dan analisis yang telah diuraikan penulis di atas dapat disimpulkan, Pertama, double crack system merupakan gagasan mengenai sistem sanksi dalam hukum pidana yang sering disebut sistem dua jalur mengenai sanksi dalam hukum pidana yang dapat kita klasifikasikan menjadi saksi pidana dan tindakan. Sanksi pidana lebih menekankan unsur pembalasan, sedangkan sanksi tindakan bersumber dari ide dasar perlindungan masyarakat dan pembinaan atau perawatan yang melanggar hukum tersebut Kedua,sanksi tindakan yang diatur dalam pasal 81 ayat 7 UU 17 tahun 2016 tentang perlindungan anak tersebut telah berbeda serta melenceng dari ide dasar sanksi tindakan dalam prinsip double crack system sebab lebih mengarah kepada penjeraan dan akan menimbulkan penderitaan bagi pelaku. ide dasar sanksi tindakan harusnya berorientasi pada perbaikan prilaku pelaku kejahatan.

\section{Daftar Pustaka}

Adithya, Andreas, and Maharani Nurdin. "Penerapan Peraturan Kebiri Kimia Bagi Pelaku Kekerasan Seksual Terhadap Anak." Jurnal Kertha Semaya Volume 9, no. 4 (2021): 643-59. DOI: https://doi.org/10.24843/KS. 2021.v09.i04.p08.

Afifah, Wiwik. "Kewenangan Dokter Dalam Melakukan Eksekusi Hukuman Kebiri." Al-Daulah Jurnal Hukum Dan Perundangan Islam Volume 10, no. 2 (2020): 304-35. DOI: https://doi.org/10.15642/ad.2020.10.2.303-335.

Alam, Kodrat. "Menakar Keterlibatan Dokter Dalam Pelaksanaan Tindakan Kebiri Kimia Bagi Pelaku Kekerasan Seksual Terhadap Anak." Jurnal Hukum Unissula Volume 36, no. 2 (2020): 93-116. DOI:https:// doi.org/10.26532/jh.v36i2.7561.

Amrunsyah. "Impian Yang Terabaikan: Implementasi Tujuan Hukum Dan Hukum Pidana Di Indonesia." Legalite Jurnal Perundang-Undangan Dan Hukum Pidana Islam Volume 4, no. 2 (2019): 181-204.DOI: https://doi.org/10.32505/legalite.v4iII.1316.

Anwar, Yesmil, and Adang. Pembaharuan Hukum Pidana (Reformasi Hukum 
Pidana). Jakarta: Gramedia, 2008.

Bakhri, Syaiful. "Pengaruh Aliran-Aliran Falsafat Pemidanaan Dalam Pembentukan Hukum Pidana Nasional." Jurnal Hukum Ius Quia Iustum Volume 18, no. 1 (2011): 136-57. DOI:https://doi.org/10.20885/iustum .vol18.iss1.art8.

Diva, I Putu Reza Bella Satria, and I Gusti Agung Ayu Dike Widhiyaastuti. "Relevansi Pengkualifikasian Sanksi Kebiri Kimiawi Sebagai Sanksi Tindakan Dalam Hukum Pidana." Kertha Wicara: Journal Ilmu Hukum Volume 8, no. 1 (2018): 1-15. https://ojs.unud.ac.id/index.php/ kerthawicara/article/view/49334.

Efiyanti, Mellisa, and Gunawan Widjaja. "The Implementation of Chemical Castration Sanctions against Convicts of Child Sexual Crimes in Indonesia by Doctors." Journal of Legal, Ethical and Regulatory Issues Volume 24, no. Special Issue 1 (2021): 1-15. https://www.abacademies.org/ abstract/the-implementation-of-chemical-castration-sanctions-againstconvicts-of-child-sexual-crimes-in-indonesia-by-doctors-11059.html.

Farid, Zainal Abidin. Hukum Pidana 1. Jakarta: Sinar Grafika, 2007.

Hasanah, Nur Hafizal, and Eko Suponyono. "Kebijakan Hukum Pidana Sanksi Kebiri Kimia Dalam Perspektif HAM Dan Hukum Pidana." Jurnal Megister Hukum Udayana Volume 7, no. 3 (2018): 305-17. DOI: https://doi.org/ 10.24843/JMHU.2018.v07.i04.p06.

Jamaludin, Ahmad, and Mohammad Sayid Rifqi Noval. "Pemidanaan Kebiri Terhadap Pelaku Kejahatan Seksual Kepada Anak Perspektif Hak Asasi Manusia Dan Hukum Islam." ADLIYA: Jurnal Hukum Dan Kemanusiaan Volume 14, no. 2 (2020): 191-208. DOI:https://doi.org//doi :10.15575/ adliya.v14i2.10135.

KPAI.“Https://Www.Kpai.Go.Id/Publikasi/Kpai-Pelaku-Kekerasan-Terhadap -Anak-Tiap-Tahun-Meningkat, Diakses Pada Tanggal 12 September 2021 Pukul 22.25 WIB." www.kpai.go.id, n.d.

Leasa, E.Z. "Penerapan Sanksi Pidana Dan Sanski Tindakan (Double Track System) Dalam Kebijakan Legislasi." Jumal Sasi Volume 16, no. 4 (n.d.): 51-57. https://ejournal.unpatti.ac.id/ppr_paperinfo_lnk.php?id=93.

Lee, Joo Young, and Kang Su Cho. "Chemical Castration Fo Sexsual Offenders: Physician' View." JKMS (Journak Korean Medical Science) Volume 28, no. 2 (2013): 171-72. DOI: http://dx.doi.org/10.3346/jkms. 2013.28.2.171.

Mantelan, Vitorio. "[Kompas] Komnas PA: Ada 2.700 Kasus Kekerasan Terhadap Anak Selama 2020, Mayoritas Kejahatan Seksual, Diakses Dari." Kompas, 2020. https://megapolitan.kompas.com/read/2021/ 01/04/ 15361151/komnas-pa-ada-2700-kasus-kekerasan-terhadap-anak- 
selama-2020-mayoritas.

Mardiya, Nuzul Quraini. "Penerapan Hukuman Kebiri Kimia Bagi Pelaku Kekerasan Seksual." Jurnal Konstitusi 14, no. 1 (2017): 215-33. DOI: https:// doi.org/10.31078/jk14110.

Marzuki, Peter Mahmud. Penelitian Hukum Edisi Revisi. Jakarta: Kencana Prenada Media Group, 2014.

Nawawi, Barda. Kapita Selekta Hukum Pidana. Bandung: Citra Aditya Bahkti, 2003.

Nurdiana, Meita Agustin, and Ridwan Arifin. "Tindak Pidana Pemerkosaan: Realitas Kasus Dan Penegakan Hukumnya Di Indonesia." Jurnal Untidar Volume 3, no. 1 (2019): 52-63. DOI:http://dx.doi.org/10.31002/ lh.v3i1.

Park, Hyungsoon. "Recent Amandements to South Korean Criminal Law: Conforting Child Sexsual Abuse." Australian Journal of Asian Law 14, no. 2 (2013): Article 6: 277-281. https://doi.org/Park, Hyungsoon, Legislative Update: Recent Amendments to South Korean Criminal Law: Confronting Child Sexual Abuse (December 18, 2013). Australian Journal of Asian Law, 2013, Vol 14 No 2, Article 6: 277-281, Available at SSRN: https://ssrn.com/abstract $=2369117$.

Rahawarin, Ahmad Rifai. "Tiga Sanksi Hukum Pidana, Ide Pembaharuan Saksi Hukum Pidana Nasional.” Jurnal Legal Pluralism Volume 7, no. 2 (2017): 144-76.http://jurnal.uniyap.ac.id/jurnal/index.php/Hukum/article/ view /505:

Ramadhani, Gita Santika, Barda Nawawi Arief, and Purwoto. "Sistem Pidana Dan Tindakan 'Double Track System' Dalam Hukum Pidana Di Indonesia." Jurnal Diponegoro Law Review 1, no. 4 (2012): 1-9.http:// ejournal-s1.undip.ac.id/index.php/dlr.

Sasmita, Luh Nia, and Gde Made Swardhana. "Sanksi Kebiri Kimia Dalam Konteks Pembaharuan Hukum Pidana Di Indonesia." Jurnal Kertha Semaya Volume 9, no. 7 (2021): 1121-30. DOI: https://doi.org/10.24843/KS. 2021.v09.i07.p04.

Sholehudin, M. Sistem Sanksi Dalam Hukum Pidana-Ide Dasar Double Track System Dan Implementasinya. Jakarta: Raja Grafindo Persada, 2007.

Supiyati. "Kebijakan Hukum Kebiri Kimia Terhadap Pelaku Kejahatan Seksual Dalam Perspektif Pemidanaan." Rechtsregel Jurnal Ilmu Hukum Volume 3, no. 2 (2020): 247-58. DOI: http://dx.doi.org/10.32493/rjih.v3i2.8093.

Suponyono, Eko. "Kebijakan Perumusan Sistem Pemidanaan Yang Berorientasi Pada Korban." Jurnal MMH Volume 41, no. 1 (2012): 29-40. DOI: https://doi.org/doi: 10.14710/mmh.41.1.2012.29-41.

Suwarnatha, I Nyoman Ngurah. “Tujuan Pemidanaan Sanksi Tindakan Kebiri 
Kimia Bagi Pelaku Kekerasan Seksual Terhadap Anak Prosiding, "Merekontruksi Ilmu Hukum Dan Ilmu Sosial Dalam Membangun Karakter Bangsa." Seminar Nasional Hukum Dan Ilmu Sosial Ke 2 Volume 2, no. 2 (2018). http://eproceeding.undiksha.ac.id/index.php/SENAHIS/ index.

Widodo, Supriyadi, and et. al. Menguji Euforia Kebiri: Catatan Kritis Atas Rencana Kebijakan Kebiri (Chemical Costration) Bagi Pelaku Kejahatan Seksual Anak Di Indonesia. Jakarta Selatan: Aliansi 99 Tolak Perppu Kebiri, 2016.

Wiharyangti, Dwi. "Implementasi Sanksi Pidana Dan Sanksi Tindakan Dalam Kebijakan Hukum Pidana Di Indonesia." Jurnal Pandecta Volume 6, no. 1 (2011): 80-85. DOI: https://doi.org/10.15294/pandecta.v6i1.2326.

Yulio, Gusti Ngurah. "Tinjauan Yuridis Terhadap Hukuman Kebiri Terhadap Pelaku Kekerasan Seksual Kepada Anak." Jurnal Kertha Wicara FH Universitas Udayana Volume 7, no. 2 (2018): 1-9. https://ojs.unud.ac.id/ index.php/kerthawicara/article/view/39473.

Zulfa, Eva Achjani. "Pergeseran Paradigma Pemidanaan Di Indonesia." Jurnal Hukum Dan Pembangunan Fakultas Hukum Universitas Indonesia Volume 36, no. 3 (2006): 399. DOI: http://dx.doi.org/10.21143/jhp.vol36.no3.1256.

(C) 2021 by the authors. Submitted for possible open access publication under the terms and conditions of the Creative Commons Attribution Share Alike (CC BY SA) license (https://creativecommons.org/licenses/by-sa/4.0/). 